\title{
Effect of nitrogen, phosphorus and potassium on growth and yield of golden rod (Solidago canadensis L.) cv. LOCAL
}

\author{
A.B. SAVALIYA AND J.D. VALA* \\ Department of Horticulture, College of Agriculture, Junagadh Agricultural University, JUNAGADH (GUJARAT) \\ INDIA
}

\begin{abstract}
An experiment was conducted to study the effect of nitrogen, phosphorus and potassium on growth and yield of golden rod (Solidago canadensis L.) cv. LOCAL using twelve treatment combinations consisting of three levels of nitrogen viz., 150,200 and $250 \mathrm{~kg} / \mathrm{ha}$, two levels of phosphorus i.e., 100 and $150 \mathrm{~kg} / \mathrm{ha}$, two levels of potassium 50 and $100 \mathrm{~kg} / \mathrm{ha}$ were tried in Randomized Block Design with factorial concept (FRBD) with three replications. The results revealed that the application of nitrogen @ $250 \mathrm{~kg} / \mathrm{ha}$, phosphorus $150 \mathrm{~kg} / \mathrm{ha}$ and potassium $100 \mathrm{~kg} / \mathrm{ha}$ (half dose of nitrogen and full dose of phosphorus and potash at the time of planting and remaining half dose of nitrogen at 30 days after planting) significantly increased growth parameters viz., plant height, plant spread, fresh and dry weight of plant, number of suckers per plant and yield attributes like fresh and dry weight of panicles, number of panicles per plant and number of panicles per hectare.
\end{abstract}

Key Words : Golden rod, Solidago canadensis, Nutrients, Cut flower

View Point Article : Savaliya, A.B. and Vala, J.D. (2015). Effect of nitrogen, phosphorus and potassium on growth and yield of golden rod (Solidago canadensis L.) cv. LOCAL. Internat. J. agric. Sci., 11 (1): 108-111.

Article History : Received : 08.08.2014; Revised : 18.11.2014; Accepted : 04.12.2014

\footnotetext{
* Author for correspondence
} 